\title{
How Would Parents Think about "Children's Learning in Advance and Winning in the Beginning"
}

\author{
Hung-Chang Lee', Mei-Ju Chou, ${ }^{2, *}$ \\ ${ }^{1}$ Department of Early Childhood Education, Taiwan Shoufu University, Taiwan \\ ${ }^{2}$ Department of Early Childhood Education and Center for Teacher Education, National Pingtung University, Taiwan
}

Copyright (C) 2015 by authors, all rights reserved. Authors agree that this article remains permanently open access under the terms of the Creative Commons Attribution License 4.0 International License

\begin{abstract}
The study aims to explore Taiwan preschool parents' parenting belief in "children's learning in advance and winning in the beginning" and whether the parenting source differs because of parents' family background. With the appropriation $0.5 \%$ categorized as level random selection, 949 young children were selected, and the 709 valid questionnaires were retrieved. The outcomes were concluded as follows. (1) Preschool Parents agree on "the earlier the children participate in brain potential activities, the better the children learn; however, comparing with parenting concept, the real parents' participation rate is less 3.34. (2) Comparing with male parents, female parents emphasizes more on "the earlier the children participate in brain potential activities, the better the children learn; considering the parents' education degree and living area, parents of lower education degree and living far away from city emphasize more on "the earlier the children participate in brain potential activities, the better the children learn. (3) There is a significant difference in parents' parenting belief among the living areas within Taiwan. After the mediating effect of parents' educational degree, the family background living area factor of "near and far away from" city decreases its own influence.
\end{abstract}

Keywords Preschool Parents, Parenting Recognition, Parenting Practice

\section{Introduction}

During human beings' revolution process, the concern on "early childhood education period" gains more and more emphasis, for children plays significant role in family education and parent-child relationship (Heywood, 2004)[1]. Many researches under the modernism currency, the parenting concept course are changing with the time. The study aims to explore preschool parents' parenting concept of "learning in advanced and winning in the beginning," and further to investigate parents' practical attitude in handling with children's learning in their preschool period.

Browne (2011) [2]pinpointed that "child-centred" parenting model and parent-child quality relationship gain more and more emphasis with children's birthrate greatly decreases recently. It also reflected the popular topic of "winning in the beginning" in Taiwan's newspaper, magazines, and related journal (Chao, 2011)[3]. These topics include the brain potential development from children's birth, the training for hands-eyes harmony and muscle development, and finger print characteristic analysis (Lee, 2007) [4], other topics covered the approval in arranging children learning English as earlier as possible (Li, Chiou, \& $\mathrm{Lu}, 2007$ ) [5], and the children who learn talented activities have become trendy currency in Taiwan (Honore, 2013; Su, 2005) [6][7].

Though the discourse on children's brain potential development, finger print characteristic analysis, and parents' support in arranging children learning English as earlier as possible all intertwined with "more stimulus, more brain potential development," "more excitement, more intelligent," "early childhood education period is the key period for brain development," and "more involvement with talented activities, higher academic achievements." (Blakemore \& Frith, 2005;Bruer, 1999) [8][9]. Especially in baby's and children's product advertisement and parenting journal and parents' discussing opinions with each other, those content continuously appear. However, in this study, we would like to explore the appropriate answer to the question. Is it correct for children' learning in advance or learning as earlier as possible lead to children's later higher academic achievements or higher intelligence brain development? (Hung, 2006/2009: Winner, 2006) [10][11][12]. To conclude, with the cultural background in East area, parents are under much more parenting pressure than the parents in Western area. Parents in Taiwan are so afraid of missing their children's key learning period; hence, in order not to make children have lower learning effectiveness, learning in advanced has already become the culture in Taiwan education system for a long time. With those above research and discourse, it is really important for parents to realize the significance of understanding the parenting atmosphere, concept and value in modern society in Taiwan. Though this study is not to help parents check the truth or false of these information. The study aims to focus on the preschool parents' parenting concept and reality of "winning in the beginning," and try to realize whether there 
is a consistent change currency from parents' different age, gender, residence area and educational degree. The results of the study is expected to offer parents further judgment and understanding basis in parenting concept.

\section{Literature Review}

With the coming of postmodernism, humanity and reason optimism brings different parenting concept and parenting role. It focuses on children's future potential and development (Huang, 2004) [13]. Parents' anxiety comes from the worry about children's learning (Honore, 2013)[6]. A lot of parents in Taiwan are so afraid of the fact that their children learn too little and too late. This attitude and recognition is very true in Chinese society where parents expect their children to be the best person in the future (Chao, 2011) [3]. It also pushes early childhood education in higher status, and parents need to pay much attention in children's educating and parenting manner. However, what children express outward are not under their parents' expectation eventually (Ching, 1991)[14].

The modernism thinking emphasizes on "children-centred," and children are required to go to learn all kinds of potential-cultivated or talent-developed courses because of the fact that everyone goes to learn those courses after class. In accordance with (Chao, 2011; Huang \& Chen, 2008) [3][12] , many parents ask their children to learn those talented courses because of the society expectation. In Chinese society, parents believe that children's participating in many talented courses might be helpful in their academic achievements. With the high expectation for children and do their best in meeting children's needs are so popular and common in Taiwan education system; therefore, children learn all kinds of talented courses from preschool age and they have little time in exercising, parent-child interaction, entertainment and sleeping (Lee \& Tu, 2009)[13]. This helps us to recognize the children-centred parenting. With Chao (2011) [3] research in primary schools' parents, $74 \%$ parents express their worry in "their children learn too little when they are very young," and this situation happens in the parents who cares and tenderly treats children.

In this study, concerning winning in the advanced learning concept, there are three view of points including brain potential development, finger prints characteristics investigation and learning English as early age as children can do. In many newspaper, advertisement, magazines, articles, people are guided that more involvement and excitement might lead to higher quality brain development (Blakemore \& Frith, 2005; Bruer, 1999)[8][9]. As Kotulak (1996) [14]mentioned that the more connection of brain nerve, the more intelligent the children are. Therefore, the more opportunities in offering children exploration multiple kinds of toys, blocks, and puzzles might help children gain higher intelligence in learning. Besides, Hirsh-Pasek, Golinkoff and Eyer (2004)[15] compared children's brain development as flexible clay, children's brain will be completely cultivated with full stimulus. However, Hung
(2006/2009) [10][11]suggested that daily life environment stimulus in young children's life is enough; therefore, too many excitements for young children might hamper children's brain development. While young children grow up, their learning and intelligence achievements might have better expression. In Taiwan, in accordance with Hung (2009) [11], finger prints characteristic investigation are so popular that parents deeply believe the results of investigation in highly related with children's future potential development. Chung (2008) [16] suggested that the finger prints characteristics investigation could be applied in early childhood education for its function might analyze human beings' brain gene and cell. Parents are so glad to gain the information of their children's future potential development and it becomes a trend that parents could appropriately predict and offer children suitable learning mechanism (Chung, 2008) [16]. However, contrary to this point of view, some research pinpointed that there is little relationship between this investigation and children's brain development (Hung, 2006)[10].

Regarding children's learning English as earlier age as they can; there are many different points of view. What parents worry is that it seems that even preschool children are learning English in some of their preschool environments, in case their children are not able to learn English in this key time, maybe their children will have negative effects in further academic achievements. In other words, parents put their early childhood experience in having little chances learning English as the basis for the modern children's learning English reflection. However, parents are so confused about in what age shall children learn English and to what extent would their children have quality learning achievements. Researches pointed that from biology perspective in researching children and adults learning second language, there is not sufficient proof in showing the direct interrelationship between brain nerve development and language learning mechanism(Wu \& Chang, 2004) [17] suggest that there is always opportunity for children to learn language in any certain period. In children's learning language stage, in fact, we have to develop children's mother language basis. With the strong foundation of mother's language reading, writing, speaking, listening ability, children will build their confidence in themselves. With too much push children's learning English might decrease children's time in other valuable activities (Wu \& Chang, 2004) [17]. Wu (2009) [18] suggested that preschool children learn English is acceptable; however, it is based on parents' correct concept and attitude in leading children naturally and healthily getting familiar with second language. Parents' concept in parenting and in expectation for children's learning means a lot.

\section{Method}

\section{Research Framework}

Based on research motivation and literature review, the framework is elaborated as follows. 


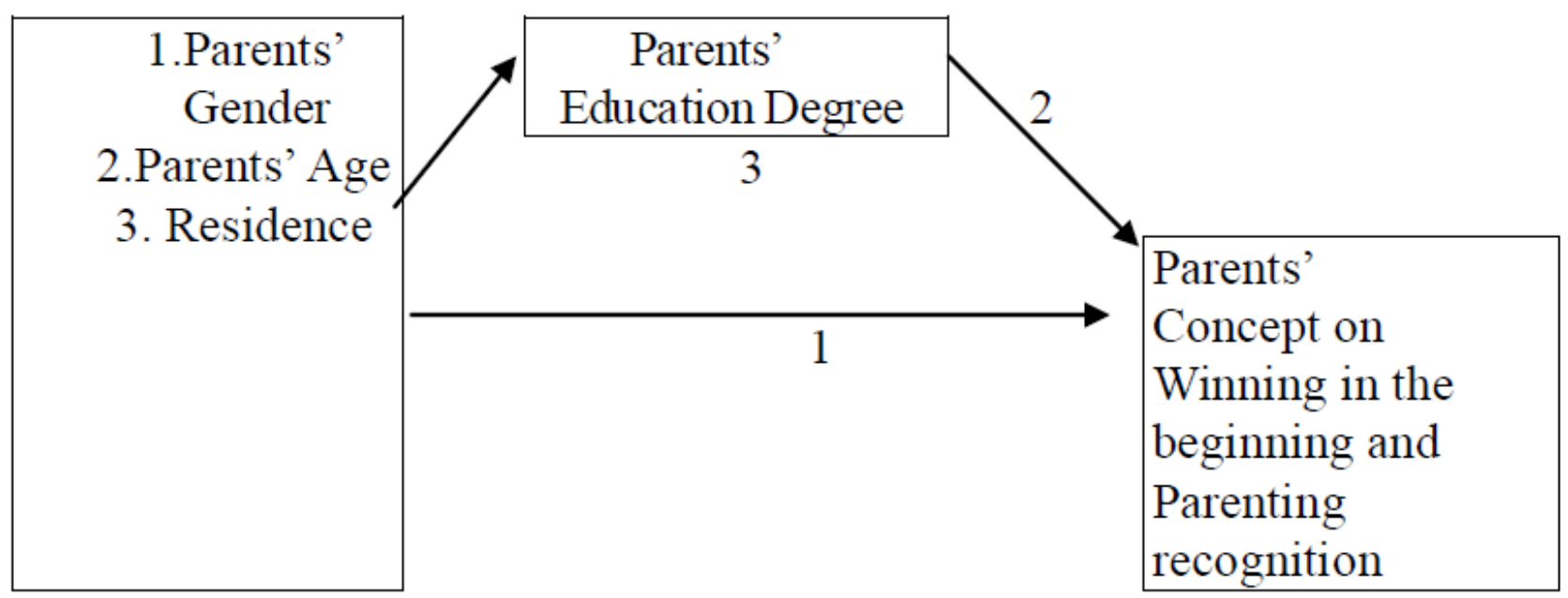

Figure 1. Research Framework

In the research framework, the percentage appropriation mode is adopted to explore parents' concept on winning in the beginning and parenting recognition. Further, Tabulated statistics and ANOVA are adopted to investigate the difference and current situation of different background parents' parenting recognition resource. At last, multiple regressions are applied in parents' education degree as the mediating factor to realize the effect of parents' different education degree on parents' winning in the beginning concept and parenting recognition. The following is the hypothesis in the study.

Hypothesis 1:Parents of different gender, age, and residence have different concept on "winning in the beginning parenting model." Hypothesis 2:Parents of different education degree have different concept on "winning in the beginning parenting model. Hypothesis 3:Parents' education degree affect their parenting concept on winning in the beginning.

\section{Research Subjects and Sampling}

189792 Children in Taiwan 3283 preschools are population (Ministry of Education, 2012) [19], Samples are categorized into North, Middle, South and Island four areas, with level random sampling from county to school, in appropriation of $0.5 \%$, the supposed sampling are 949 . 931questionnaires are retrieved 709 , with the rate $76.2 \%$. In samples, father parents $33 \%$, and mothers' $63 \%$. In age, most parents are around 30 to 44 years old. In education degree, most are college degree $52 \%$. In residence, north is $35 \%$ and south is $33 \%$.

\section{Instrument}

Based on research purpose, the self-designed "Preschool Parents Parenting Concept Questionnaire" include preschool children's basic information and parents parenting concept in winning in the beginning(children's brain potential development, earlier English learners, finger print characteristic analysis and parenting recognition and practical situation ...etc six factors.). From conform to not conform, 5 to 1 point.

\section{Factors}

parents gender: father as 1, and mother as 2 in regression. parents age: under 30, 31-35, 36-40, 41 to 45, above 46 . housing: north, middle, south, island of Taiwan. Parents education degree: college as2; graduate as 3; others as 1 . Parents parenting source (children's brain development, earlier English learners, finger print assessment 6 items) with only one factor to explain $55.1 \%$ variance, with Oblique rotation, the factor is named as "concept and practice in winning in the beginning."(as Table 1).

Table 1. Factor analysis of concept and practice in winning in the beginning $(\mathrm{N}=685)$

\begin{tabular}{|c|c|c|c|}
\hline items & $\begin{array}{l}\text { Factor } 1 \text { winning } \\
\text { in the beginning }\end{array}$ & $\begin{array}{c}\text { explain } \\
\text { variance }\end{array}$ & $\begin{array}{c}\text { Accumulated } \\
\text { variance }\end{array}$ \\
\hline $\begin{array}{l}\text { 1. I believe in and attend finger print characteristic analysis to realize children's } \\
\text { character }\end{array}$ & .813 & 55.07 & 55.07 \\
\hline $\begin{array}{l}\text { 2. I think it's right that finger print characteristic analysis could help to realize } \\
\text { children's physical and psychological characteristic }\end{array}$ & .801 & & \\
\hline 3. I would have my children participate in brain potential development activity & .792 & & \\
\hline $\begin{array}{l}\text { 4. I think it is right for children to participate brain potential development activity } \\
\text { as earlier as possible in their learning period. }\end{array}$ & .742 & & \\
\hline $\begin{array}{l}\text { 5. I would make my children to learn English as earlier as possible in their } \\
\text { learning period }\end{array}$ & .666 & & \\
\hline 6. I think it is correct that advanced learning English is good for children. & .617 & & \\
\hline Characteristic Value & 3.304 & \multicolumn{2}{|c|}{ Total $=55.07 \%$} \\
\hline
\end{tabular}




\section{Validity and Reliability}

In accordance with Table 2 factor analysis, in the validity metric, these 6 topics could clearly measure our three factors. It explains that the variety value reached 55.07, which indicates construct validity. In terms of reliability, an inner insistence Cronbach's $\alpha$ was adopted. The reliability of these 6 item career topics was 0.835 . From the above results, the reliability of the questionnaire in the current research is good.

\section{Procedure}

The research aims to realize parents' parenting resource. The research process is illustrated as follows.(A)Research literature analysis and investigation;(B)Design questionnaires: in accordance with the analysis of related literature to design questioners first, and then to ask for 2 professionals of children's development and parenting education to fix the questionnaire to develop the formal questionnaire. (C)Questionnaire Sending: stratified cluster random sampling at December in 2012, complete the sampling and sending questionnaires. (D)Receiving questionnaires and data analysis, receiving questionnaires and put the data into computer, each preschool will receive the presents and souvenir for their assistance in answering the questionnaires, and the telephone contact is finished before the mailing questionnaire into preschools.

\section{Results}

From table 2, the average analysis in parenting concept resource revealed that the grade for parents' thinking about the earlier for their children to attend children's brain potential development is 3.53 , the grade for parents' thinking about that finger print characteristic analysis could help in realizing children's physical and psychological characteristic is 2.54(median equal 3), in which it shows that parents are not quite approval in this discourse description.

From the factors of preschool parents' different background to see through their winning in the beginning parenting concept and practical situation, we could realize that there is no difference between parents' age and role playing and their parenting recognition. However, in residence area, research results revealed that parents living in Northern Taiwan have lower identification than the parents living in Southern Taiwan and Islands.

Table 2. The average analysis in parenting concept resource

\begin{tabular}{cccc}
\hline Items & Average & SD & Subject \\
\hline $\begin{array}{c}\text { 1. I would love to participate in finger print characteristic analysis in realizing children's } \\
\text { physical and psychological characteristic. }\end{array}$ & 2.54 & .958 & 691 \\
\hline $\begin{array}{c}\text { p. I think it is right that finger print characteristic analysis could help to realize children's } \\
\text { physical and psychological characteristic }\end{array}$ & 2.54 & .972 & 693 \\
\hline 3. I would have my children participate in brain potential development activity. & 3.34 & 1.00 & 1.01 \\
\hline 4. I think it is right for children to participate brain potential development activity as \\
earlier as possible in their learning period. & 3.53 & 694 \\
\hline 5. I would make my children to learn English as earlier as possible in their learning period & 3.27 & 3.24 & 709 \\
\hline 6. I I think it is correct that advanced learning English is good for children. & .991 & 694 \\
\hline
\end{tabular}

Table 3. ANOVA in each background factor

\begin{tabular}{|c|c|c|c|c|c|c|c|}
\hline & Average & SD & $\mathrm{F}$ & Free & Eta & Sig. & Scheffe \\
\hline Role & & & .908 & 2 & .052 & & \\
\hline 1 father & 3.01 & .80 & & & & & \\
\hline 2 mother & 3.04 & .71 & & & & & \\
\hline 3others & 3.23 & .82 & & & & & \\
\hline Age & & & 1.120 & 4 & .081 & & \\
\hline 1.under 29 & 3.08 & .69 & & & & & \\
\hline $2.30-34$ & 3.11 & .71 & & & & & \\
\hline $3.35-39$ & 2.99 & .69 & & & & & \\
\hline $4.40-44$ & 2.97 & .83 & & & & & \\
\hline 5.above 45 & 3.09 & .89 & & & & & \\
\hline Residence & & & 9.746 & 3 & .203 & * & $1<3,4$ \\
\hline 1North & 2.87 & .79 & & & & & \\
\hline 2Middle & 3.01 & .65 & & & & & \\
\hline 3South & 3.21 & .70 & & & & & \\
\hline 4Island & 3.26 & .84 & & & & & \\
\hline
\end{tabular}


Table 4. ANOVA in each background education degree

\begin{tabular}{|c|c|c|c|c|c|c|c|}
\hline Where are fathers coming from & Average & $\mathrm{SD}$ & F Test & freedom & Eta & Sig & Scheffe' \\
\hline \multicolumn{8}{|l|}{ role } \\
\hline 1 father & 1.85 & .722 & 4.870 & 2 & .117 & $*$ & $1>32>3$ \\
\hline 2 mother & 1.78 & .623 & & & & & \\
\hline 3others & 1.42 & .584 & & & & & \\
\hline \multicolumn{8}{|l|}{ Age } \\
\hline 1.under 29 & 1.55 & .579 & 10.353 & 4 & 236 & $*$ & $3>1,3>2$ \\
\hline $2.30-34$ & 1.69 & .577 & & & & & $3>5,4>1$ \\
\hline $3.35-39$ & 1.93 & .650 & & & & & $4>5$ \\
\hline $4.40-44$ & 1.90 & .702 & & & & & \\
\hline 5.above 45 & 1.50 & .667 & & & & & \\
\hline \multicolumn{8}{|l|}{ Residence } \\
\hline 1 North & 1.89 & .666 & 5.212 & 3 & .147 & $*$ & $1>3$ \\
\hline 2Middle & 1.82 & .667 & & & & & \\
\hline 3South & 1.69 & .616 & & & & & \\
\hline 4Island & 1.60 & .720 & & & & & \\
\hline
\end{tabular}

From Table 4, parents' education degree is higher than other caregivers'. Parents from 35-44 have higher education degree than others. Parents under 29 years old almost have preschool children and their marriage situation happens in the period of their graduating from senior high school in Taiwan. Obviously, parents from Northern Taiwan have higher educational degree than the parents from Southern Taiwan.

From the further regression analysis of background on education degree, the research revealed that other parenting role (such as grandmother and grandfather) has the lowest educational degree compared with the mother role; and the Northern Taiwan parents have obviously much higher educational degree than the parents from Southern Taiwan.

Table 5. Regression Analysis on preschool parents' educational degree

\begin{tabular}{cccc}
\hline & $\mathrm{b}$ & $\beta$ & $\mathrm{t}$ test \\
\hline Mother as control group & & & \\
Father & .057 & .041 & 1.045 \\
Others & -.377 & -.103 & $-.657^{*}$ \\
Age & .025 & .039 & .980 \\
Southern Taiwan(control group) & & & \\
Northern Taiwan & .187 & .135 & $\mathbf{3 . 0 9 8}$ \\
Middle Taiwan & .127 & .084 & 1.954 \\
Islands & -.083 & -.031 & -.778 \\
\hline constant & 1.167 & & \\
Sampling & 708 & & \\
R Square & .035 & & \\
\hline
\end{tabular}

From Table 6, the research results revealed that parents from Northern Taiwan, compared with parents from Southern Taiwan, have lower approval and identification in winning in the beginning parenting recognition and practical situation. After adding into educational degree, the research found out that the educational degree had a quite higher influence impact factor, and the residence $\beta$ value decreases a lot. In other words, the higher the parents' education degree, the lower approval and identification of parents' parent recognition in winning in the beginning. The mediating factor of education degree had a lot of influence on parents' parenting concept and practical reality.

Table 6. Regression Analysis

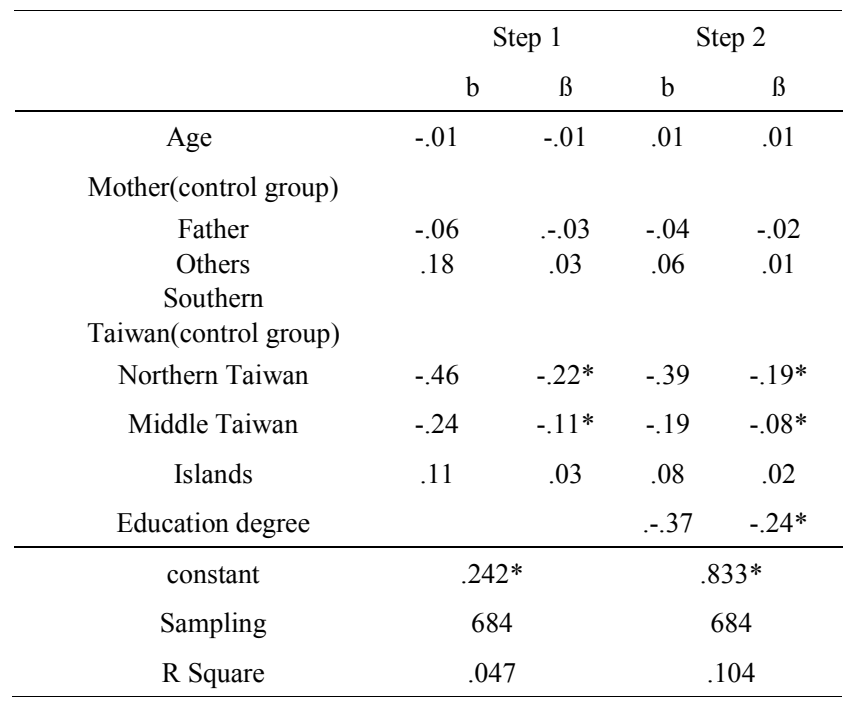

\section{Discussion}

The topics discussed in the study include children's brain potential development, finger print characteristic analysis, the earlier the better for children to learn English, the parenting recognition in children's learning in the beginning. All those discourses are based from professional scholars (Winner, 2006; Huang, 2004) [20][21]; however, it might 
not be real in reality parenting concept in Taiwan. Though the study is not to criticize the truth or false of this concept, it is to realize the whole appearance of Taiwan parents' parenting concept, including the effect of different parents' backgrounds on their parenting recognition (Ching, 1991)[22]. In order to clarify the appropriate and healthy parenting concept for parents, the study is expected to offer suggestions for parents to relieve some cultural parenting pressure in caring their children too much and expect too much.

For parents worry too much that whether their children learn too late would bring the negative effects in their future academic achievements. In general, for the purpose of elevating children's potential in brain and intelligence development, parents in Taiwan would love to agree the topic of the earlier the better for their children to learn English, the earlier the better for their children to involve in brain potential development, the eager to participate finger print characteristic analysis. Especially for the parents of lower educational degree, they approve a lot in making children learn earlier to win in the beginning. This parenting recognition has already been rooted in their heart. Also, they believe that through the expectation toward their children and their guiding children learn English, talented activities, and brain potential development is the identification of their unselfish love for their children (Chao, 2011) [3]. Though there is a lot of worry behind the truth, parents love to do this because everyone does the same arrangements for their children (Eliot, 1999)[23]. Obviously, children's time in attending other creative, logical, entertainment activity is limited (Wu \& Chang, 2004; Wu, 2009) [17] [24], and this topic needs further study to see the advantages and disadvantages.

Furthermore, from the effects of parents' different backgrounds on their parenting recognition and practical reality, we would be able to find out that the difference is not from parents' age and role model in their family. And the difference comes more from residence area and educational degree. Also, the higher the parents' educational degree, the lower approval in parents' parenting recognition of winning in the beginning in their children's learning period. From the questioners, another interesting idea is learning should be full of happiness through all the children's whole life, with too much emphasis on winning in the beginning might hamper children's development in learning motivation. Besides, the parenting concept in winning in the beginning might increase parents' burden in caring children. Those ideas would be very meaningful idea in further study.

\section{Conclusions}

The outcomes were concluded as follows. (A) Preschool Parents agree on "the earlier the children participate in brain potential activities, the better the children learn; however, comparing with parenting concept, the real parents' participation rate is less score 3.34. (B) Comparing with male parents, female parents emphasizes more on "the earlier the children participate in brain potential activities, the better the children learn; considering the parents' education degree and living area, parents of lower education degree and living far away from city emphasize more on "the earlier the children participate in brain potential activities, the better the children learn. Furthermore, in reality, parents would love to apply the parenting belief to children's hands-on experience. (C) There is a significant difference in parents' parenting belief among the living areas within Taiwan. After the mediating effect of parents' educational degree, the family background living area factor of "near and far away from" city decreases its own influence.

\section{REFERENCES}

[1] C. Heywood, A history of childhood: Children and childhood in the west from medieval to modern times, Polity, Massachusetts, 2004.

[2] L. Browne, An introduction of sociology, Polity, Massachusetts, 2011.

[3] H. L. Chao, An exploration of "children centered" and "parental anxiety about their children losing at the starting point" in child-rearing mentalities and relationships between parents and children, Journal of Family Education and Counseling, No. 10, pp 31-62, 2011.

[4] S. L. Lee, Don't be a helicopter parents, Common Wealth, No. 368, pp 106-115, 2007.

[5] I. S. Li, H. H. Chiou,H. S. Liu, Parents' expectation and children's learning related behaviors in English as foreign language classrooms, Journal of National Pingtung University of Education, No. 26, pp 325-342, 2007.

[6] C. Honore, The slow fix: Solve problems, work smarter, and live better in a world addicted to speed, HarperCollins, New York, 2013.

[7] H. C. Su, The relations between participation in after-school programs and talent classes and children's grades and behavioral adjustment in Tali city in central Taiwan, Chaoyang Journal of Humanities and Social Sciences, No. 3, pp 173-223, 2005.

[8] S. T. Blakemore, U. Frith, The learning brain: Lessons for education, Blackwell, Oxford, 2005.

[9] J. T. Bruer, The myth of the first three years: A new understanding of early brain development and lifelong learning, The Free Press, New York, 1999.

[10] L. Hung, The stand of brain, Common Wealth, Taipei, 2006.

[11] L. Hung, Let children's brain vitalize, Hsin-Yi, Taipei, 2009.

[12] Y. J. Huang, C. W. Chen, Academic cram schooling, academic performance, and opportunity of entering public universities, Bulletin of Educational Research, No. 54, pp, pp17-149, 2008.

[13] H. C. Lee, Y. C. Tu, A research on the talent-learning condition for children studying in kindergartens in Taiwan, Early Childhood Education, No. 296, pp 37-49, 2009. 
[14] R. Kotulak, Inside the brain: Revolutionary discoveries of how the mind works, Andrews \& Mcmeel, 1996.

[15] K. Hirsh-Pasek, R. M. Golinkoff, D. Eyer, Einstein never used flash cards: How our children really learn and why they need to play more and memorize less. St. Martin, New York, 2004.

[16] S. Y. Chung, A critical analysis on the arguments for facilitating children's brain power of parental education in Taiwan. (Unpublished master dissertation). National Hsinchu University of Education, Taiwan. 2008.

[17] H. F. Wu, \& J. R. Chang, Is it better to learn English earlier? Common Wealth, Taipei, 2004.

[18] Y. J. Wu, Don't lose the final in learning, Birds-family, No. 222, pp 47-49, 2009.

[19] Ministry of Education. Retrieved from http://www.edu.tw/pages/detail.aspx?Node=1731\&Page $=53$
14\&Index $=4 \&$ WID=31d75a44-efff-4c44-a075-15a9eb7aecd f, 2012.

[20] E. Winner, Educating the whole child: What the academic curriculum can learn from the arts. Paper presented at the conference of National Taipei University of Education: Multiple intelligent and educational research. Taipei: National Taipei University of Education, 2006.

[21] N. Y. Huang, Family education, Wu-Nan, Taipei, 2004.

[22] M. J. Ching, The relationship of parent-child in modern society, The Educator Monthly, No. 287, pp 8-28, 1991.

[23] L. Eliot, What's going on in there: How the brain and mind develop in the first five years of life, Bantam, New York, 1999.

[24] Y. J. Wu, Don't lose the final in learning, Birds-family, No. 222, pp 47-49, 2009. 